\title{
THE DEVELOPING FUTURE RADIO ENGINEERS' READING SKILLS THROUGH A DIVERSIFICATION APPROACH: A CASE OF DYNAMIC AND INFORMATIVE READING TEACHING
}

\author{
Simkova I. O., Pastushenko O. A.
}

\section{INTRODUCTION}

The integration of Ukraine into the world community in line with the globalization processes, internationalization of economies contributes to the development of international contacts in the field of radio engineering. As a result, the role of English for Specific Purposes (ESP) has been growing in the professional activities of radio engineers.

The quality of ESP training of future radio engineers has been one of the most challenging issues of professional education. The stiffening of the social, economic, and technological situation in the world and rapidly changing working conditions require future radio engineers to possess hard skills and soft skills such as flexibility, critical thinking, developed communicative competence in ESP, and the ability to implement the knowledge gained from ESP in professional activity in Ukraine and abroad. The modern labor market gives chance to qualified radio engineers, who are efficient in their professional activity, fluent in ESP, and ready for continuous professional development. Currently, the successful professional career of future radio engineers depends on their level of English language professional competence ${ }^{\top}$. About twenty years ago such requirement as knowledge of the English language was desirable but optional. Nowadays in the list of job requirements in innovative companies, the possession of level B2 (according to CEFR) ${ }^{2}$ in English moved from the list of soft skills to the list of hard skills of future radio engineers ${ }^{3}$. It is considered not only as a requirement of employers but the requirement of time due to the fact that many companies maintain international relations. Even if the company is national it needs information gained from English language sources. It should be noted that a significant part of the information is kept in the digital

${ }^{1}$ Beagon, Ú., Niall D. and Ní Fhloinn E. Problem-based learning: student perceptions of its value in developing professional skills for engineering practice. European Journal of Engineering Education. 2019. 44:6. P. 850-865. DOI: 10.1080/03043797.2018.1536114.

${ }^{2}$ About the Common European Framework of Reference for Languages (CEFR). 2020. International language standards. URL: https://www.cambridgeenglish.org/examsand-tests/cefr/ (дата звернення: 06.12.2020)

${ }^{3}$ Simkova I., Medvedchuk, A., Vaynahiy, T. The Implementation of E-campus during the Assessment of English for Specific Purposes. Universal Journal of Educational Research. 2020. 8.6 doi: 10.13189/ujer.2020.080628. 
sources and the perception of professional communication is carried out through reading. It is necessary to have the ability not only to read and translate professional information, but analyse, synthesize, summarize, transform, and implement in the professional activity.

The nature of radio engineering work is subject to changes due to appearing innovative types and kinds of activities. The future radio engineers should be ready for professional and social mobility, continuous professional development, an increasing role of intellectual work, and economic activity (changes in the technical base, organizational forms of work, the structure of companies, conditions, and requirements for the professionals). It causes a change in the structure of society, in the needs and aspirations of employees, their rights, lifestyle, and professional behaviour.

The success of the implementation of different approaches to ESP teaching and learning has a direct impact on the results of radio engineering work. Thus, the requirements for the level of English language professional competence for engineering specialists are increasing and the highly developed competence in ESP becomes a vital component of the professional competence of radio engineers.

According to Thanky ${ }^{4}$, higher professional competence in ESP ranks second place after computer literacy among the requirements for the graduates of polytechnical higher institutions and future radio engineers as well. Highly developed knowledge, skills, and abilities in ESP increase the competitiveness of radio engineers in the modern world labor market.

The fundamental characteristics of the necessity of ESP use by radio engineers are connected with the factors listed below.

In radio engineering, the professional activities of the specialists are distinguished depending on the goals and the tasks solved by them; they may include research, design and engineering, production, technological, organizational, and even managerial types of work. These types due to needs analysis determine the specifics of activities (speaking, listening, reading, or writing) more often used in ESP by radio engineers.

Due to their professional tasks, radio engineers can work with radio systems, radio circuits, and design. Specialists work with radio systems must possess knowledge, skills, and abilities to solve a problem in a complex, to design joint devices (transmitters and receivers) as entire systems. Such specialties need knowledge of a systematic approach implementation, the ability to think in large-scale categories, and to see the problem as a whole ${ }^{5}$.

4 Thanky, P. Importance of English and Communication Skills for Technical Professionals. International Journal of Scientific Research. 2012. № 3 (4). P. 211-212. DOI: 10.15373/22778179/APR2014/72.

${ }^{5}$ Hart-Rawung, P. and Li, L. Globalisation and business communication: English communication skills for Thai engineers. World Academy of Science, Engineering and Technology. 2008. 48. P. 230-330. URL: http://www.waset.ac.nz/journals/waset/v48/v4853.pdf (дата звернення: 06.12.2020). 
Radio engineers who work with circuit design must possess knowledge, skills, and abilities to design a subsystem with specified characteristics - such as signals at the input and the output. Such specialists need diligence, the ability to focus on separate parts. Radio engineers who deal with design must possess knowledge, skills, and abilities to elaborate the devices in small-scale design, to solve heat dissipation and cooling issues, to design device housings, and optimize circuit diagrams for placement on printed circuit boards.

During their professional communication, radio engineers who specialize in the small-scale design of devices use ESP differently from radio engineers who specialize in radio circuit design ${ }^{6}$.

The last decade in Ukraine is facing an increase in the number of Ukrainianforeign manufacturers, joint ventures and companies, transnational corporations engaged in engineering activities. Working in an international team increases the necessity to use ESP in different activities such as reading, writing, listening, and speaking (spoken production and spoken interaction).

Besides the ways of using ESP in professional activities are significantly dependent on the list of job responsibilities of a specialist. At the same joint venture, plant or company the list of job responsibilities of the chief project radio engineer and the radio engineering designer requires different levels of professional ESP competence.

The specifics of the specialism affect the professional communication of radio engineers, particularly the main activities. It is traditionally reflected in the fields of future engineers' training ${ }^{7}$.

These are special requirements for the use of ESP by a radio engineer to perform professional reading activities. The results of some research have shown that reading for engineers is one of the most popular types of activity, and the majority of respondents consider professional reading as one of the main activities of a radio engineer ${ }^{8}$.

The international integration of English language teaching concepts carried out within the framework of the internationalization processes aimed at the development of new conditions for ESP communication emerged in the field of higher technical education. At the same time, the development of academic mobility poses different tasks for radio engineers. They need to use professional reading to be aware of the implementation of international projects and advanced international standards in radio engineering. They need dynamic and informative kinds of reading to obtain information from foreign literature such as manuals, technical tasks, standards, and written

${ }^{6}$ Kassim, H. and Ali, F. English communicative events and skills needed at the workplace: Feedback from the industry. English for Specific Purposes. 2010. № 29 (3). P. 168-182.

${ }^{7}$ Lehtonen, T. and Karjalainen, S. University graduates' workplace language needs as perceived by employers. System. 2008. № 36 (3). P. 492-503.

${ }^{8}$ Sheeba, P. and Mohd. Hanif Ahmad. Teaching Reading: Goals and Techniques. Emerging Trends in Education. 2018. Publisher : New Delhi Publisher. 
communication in general in the case of work, internships, career enhancement abroad, etc.

The development of future radio engineers' reading skills through a diversification approach is generating considerable interest in terms of the modern technological development in Ukrainian society and the increasing variety of conditions for the use of the English language in the professional activities of radio engineers.

\section{The role of diversification approach in the development of future radio engineers reading skills}

The variety of professional conditions for the use of ESP leads to the diversification of the existing needs application of modern radio engineers and, as a consequence, in the development of reading skills. The variety of types in the professional reading of radio engineers needs at a certain moment can be considered as their diversification in the space of professional activity. There is a change in the total needs for the use of ESP under the influence of rapid scientific, technological, and economic development.

Diversification is one of the notable phenomena of our time. It is a combination of different phenomena, processes, and trends, allowing the best use of available resources and achieving goals.

In pedagogical science, the term "diversification" has been applied to the characteristics of the education system, such as multilevel education, multistage professional training, multifunctionality of higher institutions, and variability of syllabi, methods, and tasks ${ }^{9}$.

In economical science ${ }^{10}$, it is a way how economic agents use their financial resources in different spheres, so that in case if one of them is lost, it can be compensated with resources of another sphere. Throughout this study, the term means a variety of methods and tasks used to enhance students' professional reading activity due to individual needs of radio engineers, in terms of work efficiency, and as an opportunity to compensate the resources that are not always possible get. The professional reading activity of radio engineers is based on the choice by each student of his way of searching for information.

Diversification of the needs in a professional reading activity in space and in time is expressed in the needs arising in individual radio engineering activities. When a particular radio engineer moves up the career ladder or when he/she changes his/her place of work under the influence of

9 Diversification of education and learning. European Commission. 2020. URL: https://knowledge4policy.ec.europa.eu/diversification-education-learning_en(дата звернення: 06.12.2020).

${ }^{10}$ Zhao, F. Transforming Quality in Research Supervision: A knowledge-management approach. Quality in Higher Education. 2003. 9:2. P. 187-197. 
professional mobility, new individual professional reading needs arise, which also indicates their diversification. The diversification of individual needs in the use of ESP generates a need for a radio engineer to further increase the level of English language professional competence in reading, which is one of the prerequisites in continuous professional development. It is confirmed by the data of research ${ }^{11}$, which revealed that more than $50 \%$ of respondents with different work experience consider it necessary to improve their level of proficiency in professional reading. Thus, considering the existing variety of conditions for using a professional reading in ESP, radio engineers should be considered attention to both the diversification of development of English language professional reading needs in the sphere of professional activity and the diversification of individual needs.

An important feature of the diversification approach is the combination of original research methodologies with specific organizational forms of their implementation ${ }^{12}$.

Considering the diversification approach through the analysis of scientific events in the world and Ukrainian engineering education makes it possible to identify international (general) and national (local) factors that are conducive to its implementation. The international (general) factors that exist in all developed and developing countries are increased social demand for a higher level of education and the need to meet a wide range of educational needs of the population; advances in science and technology that contribute to the development of engineering disciplines, strengthening and development of interdisciplinarity teaching; rush development of information and communication technologies; ongoing processes of globalization, which affect the radio engineering education.

Among the national (local) factors are restructuring of the Ukrainian economy, which provoked a rush demand for specialties with highly developed communicative competence in ESP; a focus on the needs analysis of the radio engineers, which correlate with the increasing competition in the labor market, and contributes to the creation of new models of a professional and new relationship between employer and employee.

The diversification approach can be analyzed from a point of view of composition and system. Widely known research methods within the diversification approach are represented in the system since their systemic representation allows the most successful selection of certain methods in specific conditions.

Within the diversification approach, there are a lot of methods and tasks that can be used during the development of different types of reading skills of future radio engineers such as brainstorming, the crash study of the

${ }^{11}$ Turner, D.A. Quality in Higher Education. Sense Publishers, 2011. 117 p.

12 Offorma, G. Curriculum Diversification as a Function of Social Engineering / Restructing. Curriculum Diversification in Nigeria. 2010. P. 93-101. 
professional problem, intensification of mental activity, transformation of the professional problem, Synectic methods, intuitive search, and intuitive target search; algorithmic search and even Delphi method. The type of reading influences the methods and task selection. These methods are different but closely related to each other.

The difference between these methods is in a combination of methodology and research organization, a combination of tasks and simplest methods. However, each of these methods can be considered separately.

In organizational management, diversification is considered as a process of design and development of a multi-level solution based on a variety of objects and control methods corresponding to each level ${ }^{13}$. Integration of the diversification approach in our study is chosen due to a combination of various tasks, methods, activities aimed at preserving and maintaining the sustainability of reading skills development at different levels and in different types of reading. It allows to adapt the reading skills that must be possessed by future radio engineers to the changing requirements and conditions of the external professional environment, contributes to the creation of an effective mechanism for enhancement of the reading skills.

In our study, the diversification approach as a key factor that can support the development of skills in such types of reading as dynamic and informative consists of several interrelated methods. Riemer ${ }^{14}$ states that implementation of diversification approach in most instances includes the analysis of curricula and syllabus in ESP for future radio engineers, the study of training profiles of future radio engineers, analysis of assignments for individual tasks, analysis of assignments to assess the knowledge, skills, and abilities in professional reading, the consideration different types of reading, preparation of questionnaires for ESP teachers and future radio engineers concerning the development of reading skills, the conduction of interviews with teachers and students.

By exploiting the above-mentioned stages, we were able to identify the main problems concerning the development of knowledge, skills, and abilities in ESP, to have a general understanding of the diversification approach, its role in the socio-economic development of society, and ways of implementation during the development of reading skills of future radio engineers. With the completion of these stages, we are now ready to specify the types of reading that are required by future radio engineers while they search for relevant professional information in various sources, including the Internet. Also, when these stages have been completed we define

${ }^{13}$ Porzionato M., De Marco F. Excellence and Diversification of Higher Education Institutions' Missions. 2015. The European Higher Education Area / Curaj A., Matei L., Pricopie R., Salmi J., Scott P. (eds). Springer, Cham. URL: https://doi.org/10.1007/978-3319-20877-0_19 (дата звернення: 06.12.2020).

${ }^{14}$ Riemer, M.J. English and communication skills for the global engineer. Global Journal of Engineering Education. 2002. № 6 (1). P. 91-100. 
knowledge, skills, and abilities that have to be developed within the dynamic and informative reading. For instance, the ability of future radio engineers to identify, analyse, transform information to solve professional problems ${ }^{15}$.

Smith ${ }^{16}$ points out that the diversification approach is a combination of various methodological, organizational, psychological, technological research methods.

Despite the attempts made by some universities of Ukraine to introduce multilevel ESP training of radio engineers, the current ESP training in radio engineering education does not take into account neither the diversification approach during the ESP training, no functional languages needs of radio engineers that are necessary for their professional activity. At the same time, the results of the survey ${ }^{17}$ presented by some employers concerning the level of knowledge, skills, and abilities in ESP, demonstrate the low level of graduates in English language professional communication.

Meanwhile, the diversification approach of the need for reinforcement of different types of reading, speaking, writing, or listening in ESP is reflected in the different levels of future professional activity among students of higher technical institutions. With the general orientation of students at higher technical institutions to the use of ESP in their future professional activities (from $80 \%$ to $90 \%$ ), a certain part of radio engineers focused on the requirements of the labor market ${ }^{18}$. It is characterized by increasing motivation to learn ESP and increasing attempts to work under particular activities. For example, for radio engineering students when it comes to reading it is dynamic and informative reading. The young specialists and graduates of higher institutions admit that moving up the career ladder entails a change in their activities, duties, and responsibilities. It leads to the need to improve their English language communicative competence ${ }^{19}$.

An increasing number of studies have found that diversification is considered as one of the main global trends in the development of higher education, both in the European Union and in Ukrainian higher institutions.

15 CPD - Types and Conditions. Engineers Australia. 2014. URL: https://www.engineersaustralia.org.au/sites/default/files/content-files/201612/cpd_types_and_conditions_march_2014.pdf (дата звернення: 06.12.2020).

${ }_{16}$ Smith, D. Differentiation and Diversification in Higher Education: The Case of Private, Faith-Based Higher Education in Manitoba. Canadian Journal of Higher Education Revue canadienne d'enseignement supérieur. 2013. Vol. 43. № 1. P. 23-43.

${ }^{17}$ Titley, K. A survey of engineering education throughout the world. Engineering and Technology. URL: https://eandt.theiet.org/content/articles/2014/09/a-survey-ofengineering-education-throughout-the-world/ (дата звернення: 06.12.2020).

${ }^{18}$ Quek, A. Learning for the workplace: a case study in graduate employees' generic competencies. Journal of Workplace Learning. 2005. № 17 (4). P. 231-242.

19 Tomorrow's Engineers. URL: https://www.tomorrowsengineers.org.uk/ (дата звернення: 06.12.2020). 
Several studies, for instance ${ }^{20,21}$, have been carried out on relations between diversification and the general pedagogical principle of continuous education development, the results of creating conditions of continuous professional development in different industries, and conditions for professional training. A review of the literature on this topic found that diversification may affect various levels of higher education: the conceptual foundations suggested by the Ministry of Education and Science concerning ESP teaching and learning, the perspective proposed by the higher technical institutions, the basic requirements of employers, needs analysis made in vocational education and higher professional education, analysis of syllabi and curriculum, development of particular activities in ESP required by future radio engineers ${ }^{22}$.

The diversification of continuous professional training in ESP in engineering education is connected with the existing diversification of professional foreign language communicative needs of radio engineers during the performance of their professional activities. It is determined by some factors (specifics of economic sectors, various fields of application of ESP, various types of engineering activity, different types of such activities as reading, listening, speaking, and writing, the degree of international contacts development, the fast-developing job responsibilities and professional mobility of engineers, etc.).

The main professional fields of ESP application by radio engineers are engineering, translation, and educational activities. The work of a radio engineer in these areas is inextricably linked with professional communication in ESP. The following types can be distinguished in the field of radio engineering: research, design, production and technology, administrative, and management. In all the types of engineering activities, the role of professional information is so important that it gives grounds to assert that the main subject and result of a radio engineer's work is information. The professional information is recorded in a variety of documents.

Thus, communication needs in ESP are considered as the needs of a radio engineer in the implementation of professional activities with the help of ESP, the satisfaction of the needs is associated with the solution of professional tasks. The variety of communication needs in ESP that exist in the fast-developing requirements for professional activity of radio engineer is considered as their diversification from radio engineer professional activity perspective in space. Changes in communication need in ESP due to

${ }^{20}$ Mio, C. Towards a sustainable university - The Ca' Foscari experience. 2013. London : Palgrave and MacMillan.

${ }^{21}$ Cantwell, J. The Economics and Management of Technological Diversification. 2004. $381 \mathrm{p}$.

${ }^{22}$ Norbert, S. Diversification of higher education in Europe. A policy narrative that legitimizes resource concentration. 2016. 270 p. 
the influence of rapid scientific, technological, and economic development is considered as their diversification in time.

\section{The main aspects of dynamic and informative reading skills development}

The main source of information for professionals today is publications located on the Internet or other virtual professional planforms. At the same time, the amount of information required by engineers and radio engineers as well is increasing day by day. The problem of increasing the speed of extracting new knowledge from sources in both native and foreign languages is becoming urgent.

Among the issues related to the scientific organization of labour, the task of teaching radio engineers such techniques is dynamic and informative reading that would allow them to operate in the rapid growth of printed and digital information. The tasks that train them to perceive and process professionally relevant information, to keep acquainted with the latest publications in radio engineering with an acute shortage of time quickly and at the proper level ${ }^{23}$.

The task of a highly qualified radio engineer is to meet the requirements of scientific and technological progress, quickly and sensitively react to the latest achievements of science. The continuous professional development of radio engineers is highly dependent on how quickly the professional can extract relevant professional information on the specialty from English language sources. In this regard, the teaching of future radio engineers in higher technical institutions to read professional documents with a high speed and maximum information extraction is considered a challenge.

The diversification approach to ESP teaching involves bringing the content, organization, and learning outcomes under the social order, professional needs analysis, and employers' requirements. It means the ability to work with professional documents written in English in order to get acquainted with new technologies, discoveries, and inventions in time. It also allows future radio engineers to get oriented in the trends of modern developments in science, technology, and production. The highly developed knowledge, skills, and abilities in English language professional reading influence the ability to conduct professional meetings with foreign partners, to possess the necessary knowledge in cultural and professional communication, as well as knowledge about the norms of intercultural communication.

${ }^{23}$ Rakhimova, U.S. Improvement of Effectiveness of Teaching Receptive Types of Speech Activity to the Students of Non-linguistic Universities. Central Asian Problems of Modern Science and Education. 2018. Vol. 3. Issue. 3. Article 32. URL: https://uzjournals.edu.uz/capmse/vol3/iss3/32 (дата звернення: 06.12.2020) 
Future radio engineers are qualitatively new specialists who can create digital communications, conduct di- and polylogues with foreign partners, act as mediators in their professional area. They can create multilingual digital solutions for various companies and develop services for creating intercultural communication, to provide multicultural services and consultations, participate in transnational and international scientific and technological projects, purchase (exchange, sell) different types of services, search and exchange relevant information when interacting with representatives of transnational (international, multinational, global) companies ${ }^{24}$.

One of the first systematic studies on developing skills in different types of reading in ESP in higher technical institutions was presented in 1974 in the seminal research of Folomkina ${ }^{25}$. She proposed to divide the reading activity into skimming reading, scanning reading, reading for detail, and reading for specific information. The main weakness in past studies is that they do not attempt to consider such types of reading as dynamic and informative reading. These types of reading are aimed at the extraction of the necessary information from professional documents for a minimum period.

The reading is defined as dynamic and informative as far as it is estimated a tool for enhancement of intellectual and searching activity during the reading of professional English language texts. The methodological expediency of using the elements of dynamic reading in the process of ESP teaching as a factor in increasing the fluency of reading has been discussed.

The purpose of teaching dynamic and informative reading in ESP can be organized as the operational extraction of information for its further use in professional activity. Prokhorets, Sysa, and Rudneva ${ }^{26}$ distinguish such classification of reading as fast and slow. The fast types of reading include skimming reading, reading for detail, and reading for specific information. In fast types of reading speed is one of the main requirements, and the extraction of information can range from finding specific information to finding one single word or special detail. Slow types of reading include scanning reading, where the main task is the extraction of information from text, in particular cases the students may re-read its parts. Therefore, the reading speed is not a basic requirement in this kind of reading.

${ }^{24}$ Dill, D.D. Convergence and Diversity: The Role and Influence of University Rankings. In University Rankings, Diversity, and the New Landscape of Higher Education. Ed. by Barbara M. Kehm and Bjørn Stensaker. 2009. № 18. P. 97-116.

25 Folomkina, S.K. Teaching reading in a foreign language in a non-linguistic institution. Moscow : Vysshaya Shkola Publ, 2005.

${ }^{26}$ Prokhorets, E.K., Sysa, E.A., and Rudneva, E.L. Teaching of Autonomous Foreign Language Reading in Technical University: Criteria for the Selection of Textual Material. International Conference for International Education and Cross-cultural Communication. Problems and Solutions. Procedia - Social and Behavioral. 09-11 June 2015. P. 256-259. 
The following types of reading are also distinguished by authors as synthetic and analytical, reading with removed difficulties and without removed difficulties, prepared and unprepared, classroom and home, reading with a dictionary and without a dictionary, reading aloud and individually, etc. Baryshnikov ${ }^{27}$ emphasizes that there is a universal ability to read and further its division into types is artificial and claims that the mentioned above division of these types of reading seems to be somewhat speculative and considers them as not independent types of reading, but only stages of work with the text. Other authors ${ }^{28}$ have already noted that level possession of qualitative and quantitative parameters of the ability to read can be determined for each student individually.

However, in our opinion, a division of reading as an activity by fast and slow types is fully justified. Grabe and Stoller's ${ }^{29}$ assumptions concerning types of reading seem to be well-grounded. As far as to save time during searching the important professional information, it is more reasonable to use fast types of reading, which are aimed at extracting the required amount of information in a small amount of time. This type of reading includes dynamic reading as well. In theory, the issue of developing skills and abilities in dynamic reading is poorly studied and usually equalizes to such a concept as "speed reading".

There are usually several difficulties that cause slow reading. The first difficulty is reading articulation. Students with low developed skills in reading when meeting a complex text, use articulation more. Some scientists ${ }^{30}$ even suggest that articulation disappears with ultrafast reading, and during reading, the students operate with images mostly than with words.

The second difficulty that causes slow reading is a small sight view. The sight view is defined as a section of the text perceived by the eyes with one fixation of the glance. Those who read quickly perceive 5-6 words at a time, while those who read slowly perceive only $1-2$ words. The third difficulty is reading regressions, i.e. return eye movements to incomprehensible phrases or words. In most cases, it seems that the reader did not understand the text. After all, the text is always redundant, and repetitions of information provide

27 Барышников Н.В. Теоретические основы обучения чтению аутентичных текстов при несовершенном владении иностранным языком (Французский как второй иностранный, средняя школа : дис. ... докт. пед. наук : 13.00.02. Пятигорск, 1999. $530 \mathrm{c}$.

${ }^{28}$ Carnine, D.W., Silbert, J., Kame'enui, E.J., and Tarver, S.G. Direct instruction reading. (Ed.). Upper Saddle River. NJ: Merrill/Prentice Hall, 2004.

${ }^{29}$ Grabe, W., Stoller, F. Teaching and Researching Reading. Longman : Pearson Education, 2004.

30 Kuhn, M.R. and Stahl, S. Fluency: A review of developmental and remedial strategies. Journal of Educational Psychology. 2003. № 95. P. 1-19. 
understanding. Researchers ${ }^{31}$ claim that scientific and technical texts have redundancy that reaches $75 \%$. Practically only $25 \%$ of the words have the main meaning.

The fourth difficulty that causes slow reading is the lack of a flexible reading strategy. In the process of slow reading, the attention often switches to extraneous thoughts and items. Reading speed should vary depending on the difficulty of the professional text, the importance of reading for professional activity, and understanding of the author's concept, and the novelty of the text. A skilled reader can be flexible and often changes the reading strategy.

So, to develop skills and abilities in dynamic and informative reading, it is necessary to neutralize articulation, get rid of regressions, increase sight view, possess a clear reading program and be able to manage attention. Rasinski $^{32}$ outlines that the main advantage of dynamic reading is its fluency and productivity, and informative reading is aimed at extracting the necessary information from professional texts in a minimum time.

Thus, the definition of dynamic and informative reading is connected with two components speed and understanding. Moreover, the presence of both components is essential for this type of reading. Increasing speed without increasing reading comprehension is not reasonable.

Rupley, Blair, and Nichols ${ }^{33}$ found that these two phenomena are interdependent, they are connected by a curvilinear dependence: up to a certain moment, an increase in speed reading leads to an increase in understanding. According to Klychnikova ${ }^{34}$ after passing the critical point, which varies for different readers, an increase in speed leads to a decrease in the quality of understanding.

Since speed is an integral component of dynamic reading, training future radio engineers in such type of reading should take into account the factors that influence reading speed. ESP teachers should remember subjective and objective factors that influence the development of dynamic and informative reading skills. The extrinsic factors that responsible for the accuracy and completeness of text perception are the intellectual level of the reader, the speed of his/her mental activity, the speed of probabilistic forecasting. The intrinsic factors are the difficulties of the professional texts associated with

${ }^{31}$ Adefila, A., Graham, S., Patel, A. Fast and Slow: Using Spritz for Academic Study? Tech Know Learn. 2020. № 25. P. 1007-1027. URL: https://doi.org/10.1007/s10758-02009442-w

${ }^{32}$ Rasinski, T.V. Reading fluency instruction: Moving beyond accuracy, automaticity, and prosody. The Reading Teacher. 2006. V. 59. P. 704-706.

${ }^{33}$ Rupley, W.H., Blair T.R., and Nichols W.D. Effective Reading Instruction for Struggling Readers: The Role of Direct/Explicit Teaching. Reading and Writing Quarterly. 2009. 25:2-3. P. 125-138. DOI: 10.1080/10573560802683523.

34 Клычникова 3.И. Психологические особенности обучения чтению на иностранном языке. Москва : Просвещение, 1973. 223 с. 
features of printed or handwritten text, the functioning of the visual articulatory apparatus.

\section{CONCLUSIONS}

Our work has led us to conclude that the implementation of a diversification approach to the development of skills and abilities in reading during ESP courses can significantly increase the level of professional training in ESP, improve the quality of ESP training, and also increase the competitiveness of Ukrainian radio engineers and engineering industry in particular.

In this paper, we have considered diversification as the main general pedagogical principle that can improve the functioning and development of modern ESP teaching. During the development of future radio engineers reading skills, it allows us to propose a variety of tasks and methods, taking into account individual needs, and requirements for the specialists, as well as identify types of reading that need to be highly developed for future radio engineers.

The evidence from this study points towards the idea that diversification is an integral socio-pedagogical phenomenon and as the starting point of the development of professional competence in dynamic and informative reading in ESP. And therefore creates objective conditions not only for expanding professional knowledge, enriching experience, mastering the methods of the professional activity of students but also for the formation of integral and creative future radio engineers.

It has highlighted the importance of considering the diversification of ESP teaching, the process of creating organizational and pedagogical conditions that ensure the mutual enrichment (from language and professional point of view) of future radio engineers. The system's higher technical education train future radio engineers as a new generation of researchers, highly qualified specialists capable of carrying out the innovative activity. Diversification processes also penetrate the field of ESP teaching, where they manifest themselves in a growing variety of combinations of tasks and methods. This study has demonstrated that traditional research methods can be combined with the research activities and produce a special form of ESP teaching, which can create fundamentally new methods of teaching. The diversification approach stimulates flexibility, critical thinking, development of communicative competence in ESP, and the ability to implement the gained knowledge in professional activity. Methods proposed within this approach are brainstorming, systematic search, intensification of mental activity, algorithmic search, foresight technologies, etc.

\section{SUMMARY}

The paper deals with the implementation of the diversification approach during the development of future radio engineers' dynamic and informative 
reading skills. In this study, the concept of diversification is considered as the necessary condition in English for the specific purpose teaching of future radio engineers. The distinctive features of the diversification approach are given. The national and international factors of diversification are highlighted. The role of the diversification approach in the development of reading skills of future radio engineers is considered. Such types of reading as dynamic and informative were specified and defined. The relationship between reading speed and comprehension has been studied. The main difficulties associated with dynamic and informative reading performance in ESP are emphasized. The theoretical backgrounds of the diversification approach are relatable to the integrity of knowledge and the enlargement of the scientific knowledge integration paradigm framework is considered. The extrinsic and intrinsic factors that influence the development of dynamic and informative reading skills are presented.

\section{REFERENCES}

1. Beagon, Ú., Niall D., and Ní Fhloinn E. Problem-based learning: student perceptions of its value in developing professional skills for engineering practice. European Journal of Engineering Education. 2019. 44:6. P. 850-865, DOI: 10.1080/03043797.2018.1536114.

2. About the Common European Framework of Reference for Languages (CEFR). International language standards. 2020. URL: https://www.cambridgeenglish.org/exams-and-tests/cefr/ (дата звернення: 06.12.2020).

3. Simkova I., Medvedchuk, A., Vaynahiy, T. The Implementation of E-campus during the Assessment of English for Specific Purposes. Universal Journal of Educational Research. 2020. 8.6 doi: 10.13189/ujer.2020.080628.

4. Thanky, P. Importance of English and Communication Skills for Technical Professionals. International Journal of Scientific Research. 2012. № 3 (4). P. 211-212. DOI: 10.15373/22778179/APR2014/72.

5. Hart-Rawung, P. and Li, L. Globalisation and business communication: English communication skills for Thai engineers. World Academy of Science, Engineering and Technology. 2008. 48. P. 230-330. URL: http://www.waset.ac.nz/journals/waset/v48/v48-53.pdf.

6. Kassim, H. and Ali, F. English communicative events and skills needed at the workplace: Feedback from the industry. English for Specific Purposes. 2010. № 29 (3). P. 168-182.

7. Lehtonen, T. and Karjalainen, S. University graduates' workplace language needs as perceived by employers. System. 2008. № 36 (3). P. 492-503.

8. Sheeba, P., and Mohd. Hanif Ahmad. Teaching Reading: Goals and Techniques. Emerging Trends in Education. 2018. Publisher : New Delhi Publisher.

9. Diversification of education and learning. European Commission. 2020. URL: https://knowledge4policy.ec.europa.eu/diversificationeducation-learning_en_(дата звернення: 06.12.2020). 
10.Zhao, F. Transforming Quality in Research Supervision: A knowledge-management approach. Quality in Higher Education. 2003. 9:2. P. 187-197.

11. Turner, D.A. Quality in Higher Education. Sense Publishers. 2011. $117 \mathrm{p}$.

12. Offorma, G. Curriculum Diversification as a Function of Social Engineering / Restructing. Curriculum Diversification in Nigeria. 2010. P. 93-101.

13. Porzionato M., De Marco F. Excellence and Diversification of Higher Education Institutions' Missions. 2015. The European Higher Education Area / Curaj A., Matei L., Pricopie R., Salmi J., Scott P. (eds). Springer, Cham. URL: https://doi.org/10.1007/978-3-319-20877-0_19.

14. Riemer, M.J. English and communication skills for the global engineer. Global Journal of Engineering Education. 2002. № 6 (1). P. 91-100.

15. CPD - Types and Conditions. Engineers Australia. 2014. URL: https://www.engineersaustralia.org.au/sites/default/files/content-files/201612/cpd_types_and_conditions_march_2014.pdf (дата звернення: 06.12.2020).

16. Smith, D. Differentiation and Diversification in Higher Education: The Case of Private, Faith-Based Higher Education in Manitoba. Canadian Journal of Higher Education Revue canadienne d'enseignement supérieur. 2013. Vol. 43. № 1. P. 23-43.

17. Titley, K. A survey of engineering education throughout the world. Engineering and Technology. URL: https://eandt.theiet.org/content/articles/ 2014/09/a-survey-of-engineering-education-throughout-the-world/ (дата звернення: 06.12.2020).

18. Quek, A. Learning for the workplace: a case study in graduate employees' generic competencies. Journal of Workplace Learning. 2005. № 17 (4). P. 231-242.

19. Tomorrow's

https://www.tomorrowsengineers.org.uk/

Engineers.

URL:

20. Mio, C. Towards a sustainable university - The Ca' Foscari experience. 2013. London : Palgrave and MacMillan.

21. Cantwell, J. The Economics and Management of Technological Diversification. 2004. $381 \mathrm{p}$.

22. Norbert, S. Diversification of higher education in Europe. A policy narrative that legitimizes resource concentration. 2016. $270 \mathrm{p}$.

23. Rakhimova, U.S. Improvement of Effectiveness of Teaching Receptive Types of Speech Activity to the Students of Non-linguistic Universities. Central Asian Problems of Modern Science and Education. 2018. Vol. 3. Issue. 3. Article 32. URL: https://uzjournals.edu.uz/capmse/vol3/iss3/32_(дата звернення: 06.12.2020)

24. Dill, D.D. Convergence and Diversity: The Role and Influence of University Rankings. In University Rankings, Diversity, and the New Landscape of Higher Education / ed. by Barbara M. Kehm and Bjørn Stensaker. 2009. 18. P. 97-116. 
25. Folomkina, S.K. Teaching reading in a foreign language in a nonlinguistic institution. Moscow : Vysshaya Shkola Publ. 2005.

26. Prokhorets, E.K., Sysa, E.A., and Rudneva, E.L. Teaching of Autonomous Foreign Language Reading in Technical University: Criteria for the Selection of Textual Material. International Conference for International Education and Cross-cultural Communication. Problems and Solutions. Procedia - Social and Behavioral. 09-11 June 2015. P. 256-259.

27. Барышников Н.В. Теоретические основы обучения чтению аутентичных текстов при несовершенном владении иностранным языком (Французский как второй иностранный, средняя школа) : дис. ... докт. пед. наук : 13.00.02. Пятигорск. 1999. 530 с.

28. Carnine, D.W., Silbert, J., Kame'enui, E.J., and Tarver, S.G. Direct instruction reading. (Ed.). Upper Saddle River. NJ. Merrill/Prentice Hall. 2004.

29. Grabe, W., Stoller, F. Teaching and Researching Reading. Longman : Pearson Education, 2004.

30. Kuhn, M.R., Stahl, S. Fluency: A review of developmental and remedial strategies. Journal of Educational Psychology. 2003. № 95. P. 1-19.

31. Adefila, A., Graham, S. \& Patel, A. Fast and Slow: Using Spritz for Academic Study? Tech Know Learn. 2020. № 25. P. 1007-1027. URL: https://doi.org/10.1007/s10758-020-09442-w.

32. Rasinski, T.V. Reading fluency instruction: Moving beyond accuracy, automaticity, and prosody. The Reading Teacher. 2006. V. 59. P. 704-706.

33. Rupley, W.H., Blair, T.R., and Nichols, W.D. Effective Reading Instruction for Struggling Readers: The Role of Direct/Explicit Teaching. Reading and Writing Quarterly. 2009. 25:2-3. P. 125-138. DOI: $10.1080 / 10573560802683523$

34. Клычникова З.И. Психологические особенности обучения чтению на иностранном языке. Москва : Просвещение, 1973. 223 с.

\section{Information about the authors: Simkova I. O.,}

Doctor in Pedagogic Sciences, Professor, Head of the Department of English Language for Humanities

National Technical University of Ukraine

"Igor Sikorsky Kyiv Polytechnic Institute" 37, Peremohy avenue, Kyiv, 03056, Ukraine

Pastushenko O. A., Lecturer at the Department of English Language for Humanities National Technical University of Ukraine "Igor Sikorsky Kyiv Polytechnic Institute" 37, Peremohy avenue, Kyiv, 03056, Ukraine 